INTERNATIONAL JOURNAL OF SYSTEMATIC BACTERIOLOGY

Vol. 18, No. 1 January 1968 pp. 19-20

Copyright 1968, Iowa State University Press

\title{
DESIGNATION OF TYPE STRAINS OF 47 SPECIES OF ACTINOMYCES (STREPTOMYCES)
}

\author{
David Gottlieb \\ Department of Plant Pathology \\ University of Illinois, Urbana, Illinois
}

Many species of the genus Actinomyces (Streptomyces) have been described by members of the staff of the Institute of New Antibiotics of the Academy of Medical Sciences, Moscow, USSR. A culture of a strain of each of 47 of these species was supplied through the courtesy of Prof. G.F. Gause of the Institute to members of an international group of bacteriologists working under the auspices of the International Committee on Nomenclature of Bacteria on the taxonomy of the genus Streptomyces. Prof. Gause was asked to indicate the type strain of each species furnished by his Institute. This he has done by sending a letter to me addressed to "The Editor, International Journal of Systematic Bacteriology."

Some explanation of the list is advisable, together with one nomenclatural comment. All the species listed are placed in the genus Actinomyces by the authors. The names as listed in Index Bergeyana are regarded as validly published and legitimate. All the 47 species were transferred by Pridham, Hesseltine and Benedict ${ }^{2}$ as new combinations to the genus Streptomyces and as recorded in Index Bergeyana were validly published and legitimate with one exception. The species name Streptomyces griseoruber (Ryabova and Preobrazhenskaya) Pridham, Hesseltine and Benedict 1958,

1 Described and named by members of the Staff of the Institute of New Antibiotics, Academy of Medical Sciences, Moscow, USSR. In: "Problems in the Classification of Antagonistic Actinomycetes.". G.F. Gause, Ed. By G.F. Gause, J.P. Preobrazhenskaya, E.S. Kudrina, N. O. Blinov, I. D. Ryabova and M. A. Sveshnikova. State Publishing House for Medical Literature, Medgiz, Moscow, 1957.

2 Pridham, T.G., C. W. Hes seltine and R. G. Benedict. 1958. A guide for the classification of Streptomycetes according to selected groups: placement of strains in morphological sections. Appl. Microbiol. $\underline{6}: 52-79$. 
69 is a later homonym of another species, Streptomyces griseoruber Yamaguchi and Saburi 1955, 220. The new combination is therefore illegitimate and if the species is placed in the genus Streptomyces will require a legitimate specific epithet.

The number following the name of each species in the list from Prof. Gause is the strain number of the culture collection of the Institute of New Antibiotics.

For convenience in reference each species has been numbered. The letter from Prof. Gause follows.

\section{ACADEMY OF MEDICAL SCIENCES OF USSR INSTITUTE OF NEW ANTIOBIOTICS}

Bolshaia Pirogovskaia, 11 Moscow, USSR

To the Editor

International Journal of Systematic Bacteriology

Sir.

In connection with the International Streptomyces Project the following strains are designated as the type cultures of the species described originally by our group of investigators:

\author{
1. Actinomyces acrimycini $7699 \%$ \\ 2. A. alborubidus 476,52 \\ 3. A. albovinaceus 273,53 \\ 4. A. atroolivaceus 4776,54 \\ 5. A. aurantiogriseus $10369 / 58$ \\ 6. A. badius $1203 / 53$ \\ 7. A. bicolor 5104 \\ 8. A. bivericillatus 10204/54 \\ 9. A. chromofuscus $13638 / 58$ \\ 10. A. cinnaba rinus 1242 \\ 11. A. coeruleofuscus $2922 / 59$ \\ 12. A. coeruleorubidus $12531 / 54$ \\ 13. A. coerulescens 4562 \\ 14. $\bar{A}$. creneus $815 / 54$ \\ 15. A. cyaneofuscatus $99 / 54$ \\ 16. A. daghestanicus $2656 / 55$ \\ 17. A. flavidovirens 12287 \\ 18. A. flavot ricini $11669 ; 58$ \\ 19. $\bar{A}$. glaucescens 8731 \\ 20. A. griseoincarnatus $9673 / 55$ \\ 21. A. griseoloalbus $1875 / 54$ \\ 22. A. griseomycini 13984 \\ 23. A. griseorubens $6124 / 54$ \\ August 21,1967
}

24. A. griseoruber $2022 / 55$

25. A. griseorubiginosus 7712

26. A. griseostramineus 10381

27. A. kurssanovii 10294

28. A. lateritius 6993

29. A. hitmocidini $1823 / 55$

30. A. malachiticus $399 / 54$

31. A. mutabilis B-482

32. A. nigrescens $1800 / 54$

33. A. olivaceoviridis 11584

34. A. prunicolor 8805/54

35. A. roseofulvus 14535

36. A. roseolilacinus 14250

37. A. roseolus $5449 / 54$

38. A. roseoviolaceus $1020 / 54$

39. A. roseoviridis 3617

40. $\bar{A}$. rubiginosohelvus $10 / 53$

41. $\bar{A}$. rubiginosus 11852

42. A. toxytricini $13887 / 54$

43. A. umbrinus $1703 / 53$

44. $\overline{\mathrm{A}}$. variabilis $5557 / 54$

45. $\bar{A}$. violaceorectus 506

46. $\bar{A}$. violas cens 3959/54

47. A. viridiviolaceus $5726 / 56$

$$
\text { iS: G. F. Gause }
$$

Address of Culture Collection: See letterhead above. 